\title{
Methods for Assessing the Investment Attractiveness of Innovative Projects
}

\author{
PETRO PERERVA ${ }^{1 *}$, MAKSYM USOV $^{2}$, SVITLANA CHERNOBROVKINA ${ }^{2}$, \\ LUDMILA LARKA ${ }^{2}$, VIKTOR RUDYKA ${ }^{2}$
}

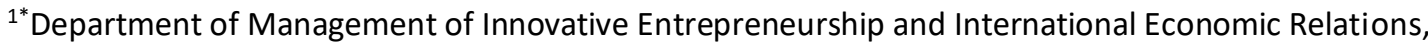 \\ NATIONAL TECHNICAL UNIVERSITY “KHARKIV POLYTECHNIC INSTITUTE”, UKRAINE, e-mail: \\ pgpererva@gmail.com \\ 2Department of Economics and Marketing, NATIONAL TECHNICAL UNIVERSITY “KHARKIV POLYTECHNIC \\ INSTITUTE", UKRAINE \\ ${ }^{3}$ State Enterprise "GIPROKOKS", UKRAINE
}

\begin{abstract}
This material examines and summarizes the basic concepts and issues of assessing the investment activities of an enterprise from the point of view of the investment climate in the industry as a whole. The main objective of this study is to determine an integral assessment of the possibilities of financing innovative projects of industrial enterprises.

The relevance of such a study is explained by the urgent need to form a more accurate and reliable assessment of the priorities of modern financing of innovative projects. The study takes into account additional factors that are applicable in the specific context of the enterprise.

In the course of the study, the following logical sequence is observed: a number of relatively simple and basic components in the structure of enterprises are distinguished, which consistently have the greatest impact on the dynamics of changes in the innovative and investment characteristics of the entire industry as a whole. The object of research is various energy enterprises of Ukraine, since they are one of the key factors that allow creating and developing a competitive world economy in terms of energysaving innovations, including on the basis of non-traditional renewable energy.

Based on the results obtained, it becomes possible to determine the integral indicators of the investment attractiveness of specific innovative projects. This technique allows you to sensibly assess all sides of the issue and make an informed management decision on the formation of the company's investment strategy.
\end{abstract}

Keywords: investment attractiveness, innovation, project, enterprises.

JEL Classification: E22, G31, Q55

Recibido:

Aceptado: 


\section{Introduction.}

One of the prerequisites for the high dynamics of development of the national economy of any state is the growth of investments in various sectors of the economy. The stable rapid growth of investment activity makes it possible to largely ensure the rise and development of the national economy, modernize enterprises, as well as develop existing industries and develop goods and services [1, 2].

There are several factors that characterize the investment attractiveness of an enterprise. Among them, one can single out the stability of the financial condition, the level of financial results, the competitiveness of the products, the degree of riskiness of investments, as well as the potential for enhancing innovation.

At the majority of modern Ukrainian enterprises, there is a serious need to search for additional sources of financing for innovation and investment projects.

Among the main problems that require the development of this industry are the following [3]:

1) Inconsistency of the current investment attractiveness with the positions held in the market;

2) The general need to improve the efficiency of economic activity.

There are various sources of financing for investment projects, which are divided into external and internal [3].

External investors may face the problem of excess demand for them. This trend leads to the need to select specific investment objects, based on the competitiveness of this object. Investment attractiveness largely characterizes the competitiveness of the project and facility. This term is a complex category that is formed on the basis of various estimated indicators of the functioning of enterprises, developers and consumers of innovative projects. The specific choice of these factors is influenced by various indicators, among which the potentially most important are specific investment goals, as well as the availability of the information provided for evaluating actions. As a result, an innovative project will be determined by a certain set of works of an innovative nature, which will be regulated by the stages of their organization and resource provision from the conception of the concept to the creation of a new product and its subsequent commercialization.

At the moment, in the context of the socio-economic and financial crisis in Ukraine, the issue of attracting investments by Ukrainian enterprises is extremely relevant. Investments in this case will play the role of an activator of comprehensive measures for the development of the enterprise, which means that they will contribute to its development and improvement of performance, as well as the overall improvement of the country's innovation climate. Consequently, the relevance of this study lies in the creation of a systematic assessment of the level of investment attractiveness of specific enterprises in the real sector of the economy.

\section{Analysis of literature data and problem statement.}

Recently, more and more attention has been paid to the problem of studying investment attractiveness from the side of scientific research. It should be noted here that at the moment there is no strict definition of "investment attractiveness". Many researchers in the context of this term mean the financial security of the enterprise. Also, in many samples of literature and regulatory documents, the terms "investment attractiveness" and "investment climate" are identical. In particular, Plaskova N. [1] and Rzayeva T. [2] hold this position in relation to the enterprise. 
Actual scientific developments offer various approaches to assessing the investment attractiveness of enterprises and their innovative projects. For example, E. Kolesnichenko [7] believes that the formation of a methodological basis for assessing investment attractiveness requires some financial analysis. Tiutlikova V. [8] and MV Prokopyeva adhere to a similar point of view. [10], which indicate the decisive role of the financial component in assessing the level of investment attractiveness of the project.

According to Safiullin, A. [3] and Nikonova T. [4], investment attractiveness is largely determined by the current stage of the enterprise life cycle. We do not deny the possible truth of this approach, however, we emphasize that, according to Naumov A. [5] and Kolmykova T. [6], the following three factors affect the investment attractiveness:

1) The presence of a favorable investment situation in the enterprise and the financial market;

2) Favorable investment climate in economic systems;

3) The presence of factors providing additional benefits of innovative projects.

Thus, we can conclude that investment attractiveness is a certain set of favorable investment and innovative conditions and advantages that are available when investing additional profit and reducing the risk of investment.

The latter position is extremely important in this definition. It touches upon the concept of risks, which, in any case, are associated with investment activities. Researchers such as Kosenko O. [11] and Kobieliev V. [12] indicate the need for mandatory consideration of potential investment risks. They suggest using several different practical approaches to assessing the level of risk of investment in innovative projects.

In parallel with this, we must not forget that investment attractiveness basically provides for the creation of a certain methodological base for comparing the investment attractiveness of a particular enterprise with the average industry investment attractiveness or with certain standard values. Thanks to the development of a specific integral indicator, it becomes possible to meet the requirements for creating a corporate assessment and adaptability of using the methodology for assessing the investment attractiveness of innovative projects at industrial enterprises.

\section{The purpose and objectives of the study.}

This article is aimed at further development of the main conceptual provisions for substantiating the level of investment attractiveness of innovative projects. The main goal of this study is to create specific scientific, methodological and practical recommendations for improving methods of managing the competitiveness of innovative projects of enterprises that are engaged in the implementation of innovations in order to increase the efficiency of economic activity.

Thanks to the achievement of this goal, it becomes possible to create conditions for the effective development of industrial enterprises on an innovative basis, as well as to ensure their effective functioning in the market.

To achieve this goal, the following tasks must be achieved:

1) Revision of the term "investment attractiveness", as well as the creation of specific tools for managing the competitiveness of innovative projects; 
2) Conducting a point assessment of individual indicators of investment attractiveness included in a single factor of investment attractiveness. This allows you to determine the average score for each single factor of investment attractiveness;

3) Formation of a rating scale that allows to characterize the level of influence of specific factors on the investment attractiveness of innovative projects of industrial enterprises;

4) Development of a system of indicators describing the level of impact of factors in accordance with the selected criteria;

5) Calculation of the integral indicator of investment attractiveness of innovative projects based on a point assessment of single factors.

\section{Materials and research methods for assessing the investment attractiveness of innovative projects.}

To form the theoretical, methodological and methodological basis of the research, the analysis of scientific research of leading scientists in the field of investment is used. Thanks to the use of the information base of such studies, it became possible to identify potential omissions associated with fragmentary approaches to determining the level of investment attractiveness of innovative projects of industrial enterprises and their impact on the level of efficiency and production, commercial and innovative activities of the enterprise.

However, researchers do not fully take into account the factors of the impact of innovative projects on investment attractiveness. It is also worth noting the lack of developments in substantiating the integral indicator of the investment attractiveness of projects based on the cluster approach.

The following general and special methods are used to achieve the research goal, as well as to solve the assigned tasks:

1) Abstract-logical and comparative analysis in the study of the essence and importance of the innovation process in the activities of industrial enterprises;

2) Grouping and systematization to determine the main factors influencing the level of investment attractiveness and their grouping into certain clusters in accordance with the requirements of machine-building production;

3) The method of expert assessment to create a scale of differentiation of the level of investment attractiveness of innovative projects;

4) System-structural method and logical generalizations to substantiate the integral indicator of investment attractiveness and the formation of the final result.

\section{The results of the study.}

The assessment of the investment attractiveness of the enterprise should be based on the analysis of the investment climate of the industry. The investment climate in the industry means a set of conditions that determine the attractiveness (or unattractiveness) of financial investments of local and foreign investors in the development of this business area $[1,2]$. Among the most important criteria that determine the favorable investment climate in the industry, first of all it is necessary to identify the following factors [3]:

a) socio-economic sustainability of the industry;

b) the level of investment potential, the availability of priority areas of investment nature;

c) use of green technologies;

d) development of production and market infrastructure; 
e) staffing of the necessary qualifications;

f) stability and progressiveness of legislation (including tax);

g) reliability of the credit and financial system, etc.

Directly the set of conditions of investment attractiveness is manifested in the presence of the following factors [4]:

a) a sufficient number of highly efficient proposals on the basis of which relevant investment projects can be developed and implemented;

b) relatively low aggregate risks of inefficient investments. The above specifics of the investment climate of the industry orientation determines the need to change the traditional methodology for evaluating investment projects.

In order to analyze the existing methods of comparative evaluation of investment projects for practical feasibility in modern market conditions of Ukraine and develop proposals for a more realistic assessment of the priority of investment projects, a survey of experts and specialists of energy companies of Ukraine was conducted. [5, 6]

Interviewed experts of enterprises during the survey spoke, from the point of view of investors. Determining the rating of the main components of investment attractiveness of enterprises is presented in Fig. 1.

Figure 1. Determining the rating of the main components of investment attractiveness of enterprises

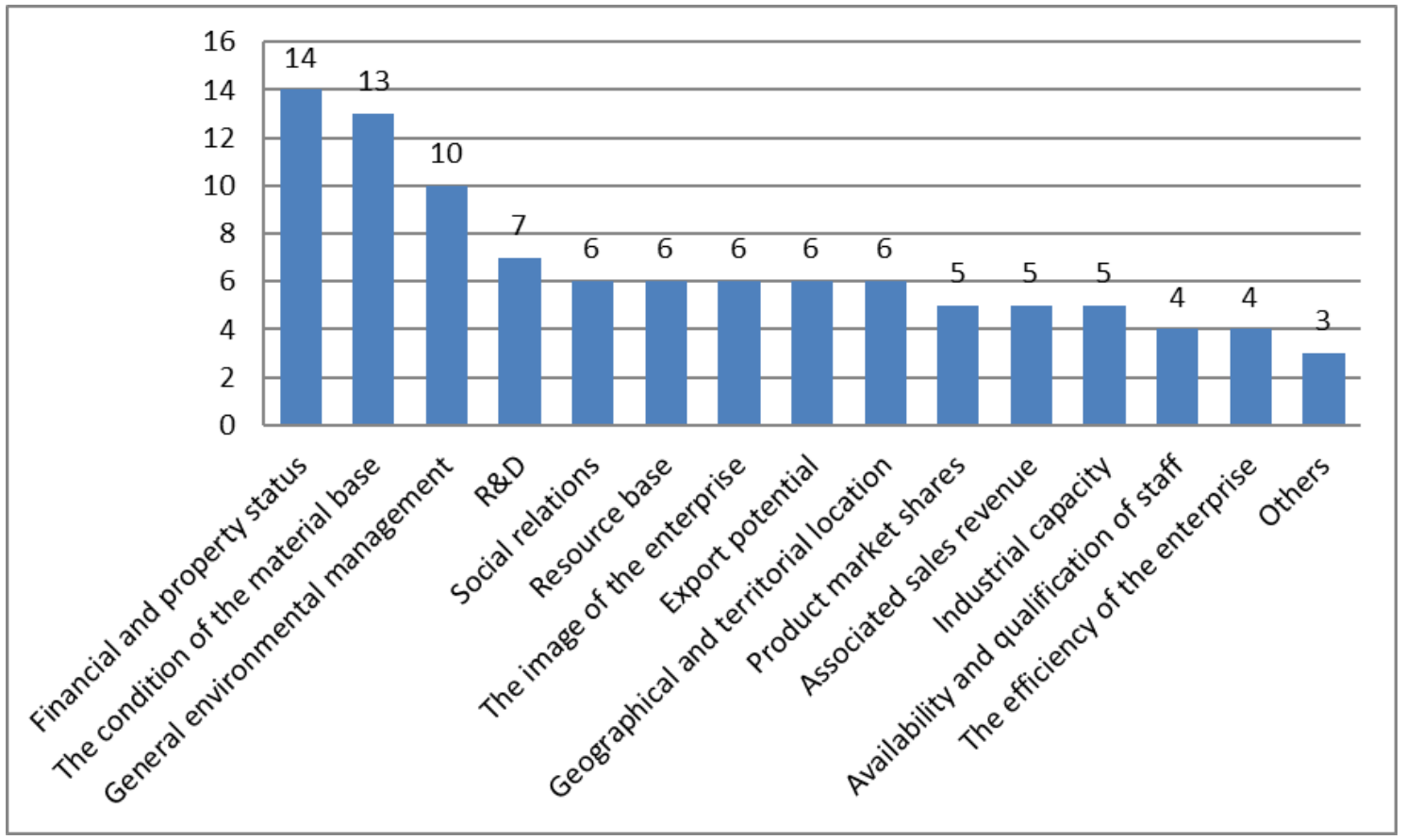

According to the final data, the analysis of the survey found that up to $85 \%$ of enterprises need investment. It was also found that the reasons and motives of the investor are different, the goals of investing are different, and accordingly, the ways of attracting investors are different. It is established that the formation of investment prerequisites and motives for investing depends on the factors of influence of external and internal environments of the enterprise $[7,13]$. In accordance with the factors of influence, which have a constant nature of 
influence, the goals of investment change. The unanimous opinion of the majority of respondents was only one goal, which does not change under the influence of external and internal factors - the goal of making a return on investment.

The first place in the ranking is occupied by the financial and property status of the enterprise as the basis of its activities. The second place in the ranking is occupied by such a component as the condition of the material base, the availability of means of production, technology and financial resources for further use. The third place is occupied by the general ecological management of the enterprise and projects, as one of classes of green technologies. It includes: reduction of air and water pollution, waste management, soil restoration, environmental monitoring. Research and development, innovation is the basis of strategic development of the enterprise and indicate the prospects and potential of the enterprise, so they play an important role in the investment attractiveness of the enterprise. Social relations have recently had a certain impact on the investment attractiveness of enterprises, as they form public opinion and the opinion of professional circles about the enterprise, its activities, prospects and other vital aspects for the formation of investment attractiveness.

Assessment of the enterprise as an object of investment can be carried out on the basis of analysis of the technical level of equipment, loading of industrial areas, resource and other restrictions, innovative development and management level in the object analysis, allows to obtain an integrated description of the enterprise as an investment object. used as a basis for the formation of investment attractiveness of the enterprise and its individual innovation projects [8]. The territorial and geographical location of the enterprise, although not of fundamental importance to investors, is no less important.

To solve the tasks it is necessary to pre-allocate in the structure of the innovative enterprise a number of relatively simple components that have the greatest impact on innovation and investment characteristics, and in relation to the selected elements to determine the criteria for assessing their condition and impact on investment attractiveness. Criteria and indicators of expert assessment of the investment attractiveness of the project can be expanded according to the specific features and needs of enterprises.

The criteria and indicators of expert assessment of the investment attractiveness of an innovative project proposed for consideration are presented in table. 1.

Table 1. Criteria and indicators of expert assessment of investment attractiveness

of an innovative project (on a 10-point scale *)

\begin{tabular}{|c|c|c|}
\hline Criterion & Indicator & $\begin{array}{l}\text { Characteristics of the investment attractiveness of the innovation project in accordance with the } \\
\text { value of expert assessment }\end{array}$ \\
\hline \multirow{2}{*}{ 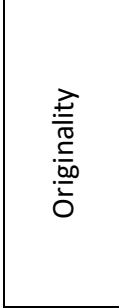 } & $\begin{array}{l}\text { The scale of } \\
\text { originality }\end{array}$ & $\begin{array}{l}\text { The project is original on a global scale }(10 \ldots 8.01) \text {. } \\
\text { The project is original in the scale of the economy segment }(8 \ldots 5.01) \text {. } \\
\text { The project is original for the enterprise }(5.01 \ldots 2) \text {. } \\
\text { The project is not original }(2,01 \ldots 0)\end{array}$ \\
\hline & $\begin{array}{l}\text { Degree of } \\
\text { originality }\end{array}$ & $\begin{array}{l}\text { High: the project is radical }(10 \ldots 8.01) . \\
\text { Medium: the project has a combinatorial character, combined with already known elements }(8 \ldots 5.01) \text {. } \\
\text { Low: the project has a modifying character (improves and complements) }(5.01 \ldots 2) . \\
\text { Originality and novelty are absent }(2,01 \ldots 0)\end{array}$ \\
\hline $\begin{array}{l}\frac{\vec{Z}}{0} \\
\frac{1}{2} \\
2\end{array}$ & $\begin{array}{c}\text { The level of } \\
\text { patent purity and } \\
\text { sub-confirmation } \\
\text { of novelty }\end{array}$ & $\begin{array}{l}\text { High: there are patents and licenses, their novelty is confirmed, there is copy protection }(10 \ldots 8.01) . \\
\text { Medium: the product is at the stage of patenting }(8 \ldots 5.01) \text {. } \\
\text { Low: the product or service is not patented, although the presence of a patent is assumed }(5.01 \ldots 2) \text {. } \\
\text { Not expected }(2.01 \ldots 0)\end{array}$ \\
\hline 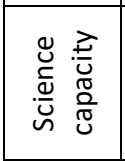 & $\begin{array}{c}\text { The level of } \\
\text { scientific security }\end{array}$ & $\begin{array}{l}\text { High-tech projects }(10(8.01) \\
\text { Medium-tech projects }(8 \ldots 5.01) \\
\text { Sphere of science-intensive services }(5.01 \ldots 2) \\
\text { Low-tech projects }(2.01 \ldots 0)\end{array}$ \\
\hline 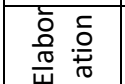 & $\begin{array}{l}\text { The degree of } \\
\text { elaboration of }\end{array}$ & $\begin{array}{l}\text { Full level of elaboration: the project differs in the presence of a clear development plan, risk forecast } \\
\text { and ways to overcome them }(10 \ldots 8.01) \text {. Sufficient level of elaboration: the project differs in the }\end{array}$ \\
\hline
\end{tabular}




\begin{tabular}{|c|c|c|}
\hline & the project & $\begin{array}{l}\text { presence of possible risks, but there are no ways to overcome them }(8 \ldots 5.01) . \\
\text { Insufficient elaboration: the project differs in the presence of a development plan, but there is no list of } \\
\text { possible risks and ways to overcome them }(5.01 \ldots 2) \text {. } \\
\text { Project not processed }(2.01 \ldots 0)\end{array}$ \\
\hline & $\begin{array}{l}\text { The level of } \\
\text { integrated } \\
\text { consideration of } \\
\text { investment } \\
\text { attractiveness } \\
\text { factors }\end{array}$ & $\begin{array}{l}\text { High: the project takes into account a variety of technical, economic, informational, environmental, } \\
\text { social and other factors }(10 \ldots .01) \text {. Average: the project differs taking into account } 3-4 \text { factors from all } \\
\text { variety }(8 \ldots 5,01) \text {. } \\
\text { Low: only } 1-2 \text { factors are taken into account in the project, all others are ignored }(5.01 \ldots 2) . \\
\text { When forming the project factors, the factors were not taken into account }(2.01 \ldots 0)\end{array}$ \\
\hline 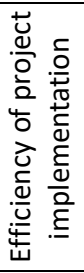 & $\begin{array}{l}\text { The effectiveness } \\
\text { of the innovation } \\
\text { project }\end{array}$ & $\begin{array}{l}\text { High level of efficiency: the project improves the production process; expands the capabilities of the } \\
\text { enterprise; provides effective management of systems, personnel, etc. }(10 \ldots 8.01) \text {. } \\
\text { Average level of efficiency on the specified parameters or high level of efficiency for the private } \\
\text { investor }(8 \ldots 5,01) \text {. } \\
\text { Low level of efficiency on the specified parameters or average level of efficiency for the private investor } \\
(5,01 \ldots 2) \text {. } \\
\text { The project is not effective enough }(2.01 \ldots 0)\end{array}$ \\
\hline \multirow{2}{*}{ 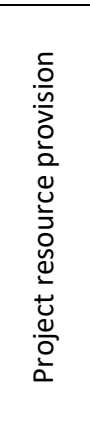 } & $\begin{array}{c}\text { The level of need } \\
\text { for special } \\
\text { training }\end{array}$ & $\begin{array}{l}\text { High: the project is implemented without special training and does not require special conditions }(10 \ldots \\
8.01) \text {. } \\
\text { Medium: special conditions are required for project implementation }(8 \ldots 5.01) . \\
\text { Low: implementation only in the presence of special conditions and special training }(5.01 \ldots 2) . \\
\text { Practical implementation of the innovative project is significantly complicated }(2.01 \ldots 0)\end{array}$ \\
\hline & $\begin{array}{l}\text { The level of } \\
\text { resource } \\
\text { provision }\end{array}$ & $\begin{array}{l}\text { High: sufficient resources (financial, human, natural, etc.) for implementation }(10 \ldots 8.01) \text {. } \\
\text { Average: incomplete provision of resources }(8 \ldots 5.01) \text {. } \\
\text { Low: there are only } 1-2 \text { resources in the region, but they are not enough to implement the project } \\
(5.01 \ldots 2) . \\
\text { Assessment of the possibility of practical implementation of the project is complicated or not carried } \\
\text { out }(2.01 \ldots 0)\end{array}$ \\
\hline 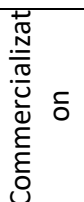 & $\begin{array}{c}\text { The scale of } \\
\text { commercializatio } \\
\mathrm{n}\end{array}$ & $\begin{array}{l}\text { Commercialization of the project on all scales, sectors of economy; the financial business model is } \\
\text { presented }(10 \ldots 8.01) \text {. } \\
\text { Commercialization in a separate segment of the economy, industry }(8 \ldots 5.01) \text {. } \\
\text { The project can be commercialized }(5.01 \ldots 2) \text {. } \\
\text { Commercialization of an innovative project is complicated }(2.01 \ldots 0)\end{array}$ \\
\hline
\end{tabular}

Note: 10 points is the best indicator

Source: authors' development

The estimated value of the integrated indicator of investment attractiveness of the innovation project (IIA) is proposed to be determined using the following dependence:

$$
I_{I A}=\sum_{n=1}^{n} \frac{\sum_{i=1}^{n} P_{i} / 10}{k}
$$

where $i$ is the numerical equivalent of the expert assessment of the $n$-th criterion; $n$ is the number of evaluation criteria; $P i$ is the weighting factor of the $n$-th criterion; $k$ is the number of experts.

When using the quantitative values of the evaluation criteria, the value of the calculated indicator of the level of investment attractiveness of the enterprise project is in the range from 0 to 10 .

Using the previously established ratios of quantitative and qualitative values of partial criteria, the level of investment attractiveness of the innovative project is proposed to be as follows: 
a) a high level of investment attractiveness, if the calculated value of the integrated indicator of investment attractiveness of the innovation project (IIA) is in the range from 8 to 10;

b) the average level of investment attractiveness, if the estimated value of the IIA is in the range from 5 to 8 ;

c) low level of investment attractiveness, if the estimated value of IIA is in the range from 2 to 5;

d) an innovative project is considered unattractive for investment if the estimated value of the IIA is less than 2.

The proposed method of determining the investment attractiveness of an innovative project was tested at 42 industrial enterprises of Ukraine. For each of the projects submitted for evaluation by different enterprises, $X_{n i}$ criteria were established (where $\mathrm{X}$ is the project evaluation criterion; $n$ is the number of criteria, $n=1, \ldots, 7 ; i$ is the expert evaluation of each criterion, $i=1, \ldots, 10)$. According to our estimates of the integrated indicator of investment attractiveness of the innovation project, the evaluation results were divided into four evaluation sectors - A, B, C and D. If the calculated value of the integrated indicator of investment attractiveness of the innovative project IIA is in the range $0 \ldots 2$, sector $D$; if the value of $I_{I A}=[2 \ldots 5]$, then $X_{n}$ falls into sector $C$; if the value of IIA $=[5 \ldots 8]$, then $X_{n}$ falls into sector $B$; if the value of $I_{I A}=[8 \ldots 10]$, then $X_{n}$ falls into sector $A$.

The results of this study are presented in table 2 and figure 2.

Table 2. Expert assessment of investment attractiveness of innovative projects at industrial enterprises of Ukraine

\begin{tabular}{|c|c|c|c|c|c|c|c|c|c|}
\hline \multirow{2}{*}{\begin{tabular}{|c|} 
Enterprise \\
(innovative \\
project), $P_{i}$ \\
\end{tabular}} & \multicolumn{4}{|c|}{ Evaluation sectors } & \multirow{2}{*}{$\begin{array}{l}\text { Enterprise } \\
\text { (innovative } \\
\text { project), } P_{i}\end{array}$} & \multicolumn{4}{|c|}{ Evaluation sectors } \\
\hline & $\begin{array}{c}A \\
(8,0 \ldots 10,0)\end{array}$ & $\begin{array}{c}\mathrm{B} \\
(5,0 \ldots . .8,0)\end{array}$ & \begin{tabular}{c|c|}
$C$ \\
$(2,0 \ldots .5,0)$
\end{tabular} & $\begin{array}{c}D \\
(0,0 \ldots 2,0)\end{array}$ & & $\begin{array}{c}A \\
(8,0 \ldots 10,0)\end{array}$ & $\begin{array}{c}B \\
(5,0 \ldots 8,0) \\
\end{array}$ & $\begin{array}{c}C \\
(2,0 . .5,0)\end{array}$ & $\begin{array}{c}D \\
(0,0 \ldots 2,0)\end{array}$ \\
\hline$P_{1} ; l_{\text {IA1 }}=7,1$ & 9,1 & $6,0 \div 6,8$ & $3,0 \div 4,1$ & - & $P_{22} ; l_{1 A 22}=6,3$ & $8,3 \div 8,7$ & $5,1 \div 5.6$ & 4,1 & 2,0 \\
\hline$P_{2} ; I_{1 A 2}=7,6$ & 8.3 & $5,1 \div 5,3$ & $4,2 \div 4,7$ & $1,0 \div 1,2$ & $P_{233} ; I_{\mid A 23}=6,2$ & $8,1 \div 8,5$ & $5,2 \div 5,5$ & 4,2 & 1.2 \\
\hline$P_{3} ; l_{I A 3}=7,9$ & 9,90 & $5,2 \div 5,8$ & 3,1 & 1,3 & $P_{24 ;} I_{1 A 24}=8,2$ & $8,7 \div 9,2$ & $5,4 \div 6,8$ & 4,9 & 1,3 \\
\hline$P_{4} ; l_{I A 4}=9,6$ & - & $7,4 \div 7,8$ & 4,2 & 0,7 & $P_{25} ; I_{I A 25}=8,2$ & 9,9 & 6,0 & 5,0 & 2,0 \\
\hline$P_{5} ; I_{1 A 5}=9,4$ & 9,22 & $6,6 \div 6,9$ & 2,1 & 1,9 & $P_{26 ;} ; l_{1 A 26}=8,2$ & 8 & & 4,9 & $1,0 \div 1,8$ \\
\hline$P_{6} ; l_{I A 6}=8,18$ & $8,7 \div 9,2$ & 8,0 & 3,5 & 2,0 & $P_{27 ;} I_{\mid A 27}=8,8$ &, 3 & 7,7 & 4,2 & 1.4 \\
\hline$P_{7} ; l_{1 A 7}=7,7$ & $9,7 \div 9,9$ & $6,9 \div 7,2$ & $3,20 \div 4,2$ & - & $P_{28 i} I_{1 A 28}=9,3$ & 9,8 & 7,6 & 5,0 & 1,2 \\
\hline$P_{8} ; I_{1 A 8}=5,4$ & - & $6,8 \div 7,3$ & - & 1,3 & $P_{29 ;} ; I_{\text {IA29 }}=6,6$ & $8,2 \div 8,6$ & 7,6 & 3,6 & 6 \\
\hline$P_{9} ; I_{I A g}=8,5$ & 8,1 & $7,2 \div 7,5$ & 3,0 & 0,4 & $P_{30} ; I_{1 A 30}=8,4$ & $9,1 \div 9,9$ & 7,7 & 3,9 & - \\
\hline$P_{10} \| A_{10}=6,1$ & 8,1 & 5,8 & 3,9 & 0,9 & $P_{31} ; I_{\mid A 31}=8,8$ & $9,5 \div 9,9$ & $7,3 \div 7,6$ & 3,9 & 0,60 \\
\hline$P_{11} ; \| A_{11}=5,4$ & 9,2 & 7,9 & 4,0 & 1,6 & $P_{32} ; I_{1 A 32}=6,9$ & 8,0 & $6,0 \div 6,8$ & 2,9 & 1,3 \\
\hline$P_{12} ; \| A_{12}=8,09$ & $9,1 \div 9$ & $6,0 \div 7,3$ & $4,4 \div 5$, & $0,1 \div 0,9$ & $P_{33 ;} I_{1 A 33}=7,5$ & 8,1 & - & $2,5 \div 3,6$ & 1,9 \\
\hline$P_{13} ; I A_{13}=8,98$ & $8,0 \div 9$ & $6,1 \div 6,6$ & 4,5 & 1,3 & $P_{34} ; I_{I A 34}=5,9$ & - & $4,2 \div 5,1$ & 3,6 & 0,9 \\
\hline$P_{14 ;} ; I A_{14}=8,0$ & 9,4 & $7,3 \div 7,6$ & 3,4 & 1,2 & $P_{35} ; I_{1 A 35}=9,0$ & 9,9 & - & - & $1, \div 2,0$ \\
\hline$P_{15} ; I_{\text {IA15 }}=9,5$ & 9,1 & 6,1 & $4,1 \div 4,3$ & $1,1 \div 1,9$ & $P_{36} ; l_{1 A 36}=4,4$ & - & 5,2 & $2,1 \div 2,6$ & 0,5 \\
\hline$P_{16} ; I_{1 A 16}=7,7$ & 8,1 & $6,5 \div 6,9$ & 4,08 & 0,6 & $P_{37 ;} l_{\mid A 37}=7,6$ & $8,1 \div 8,5$ & 5,0 & 4,8 & 0,6 \\
\hline$P_{17} ; I_{\mid A 17}=9,4$ & 9,5 & 7,80 & $2,2 \div 2,9$ & $1,5 \div 2,0$ & $P_{38,} ; l_{1 A 38}=6,6$ & - & 6,0 & $2,4 \div 4,1$ & $0,6 \div 1,0$ \\
\hline$P_{18} ; I_{\mid A 18}=7,2$ & 8,4 & 7,9 & $3,3 \div 3,5$ & - & $P_{39 ;} I_{1 A 39}=8,9$ & $9,7 \div 9,9$ & 7,3 & $4,5 \div 5,9$ & $0,1 \div 1,0$ \\
\hline$P_{19} ; I_{I A 19}=4,5$ & - & 5,3 & 2,5 & $0,4 \div 0,6$ & $P_{40} ; I_{1 A 40}=6,3$ & 8,6 & $6,20 \div 7,4$ & 5,10 & 1,1 \\
\hline$P_{20} ; I_{1 A 20}=6,38$ & $1 \div 9,8$ & - & 4,0 & 0,9 & $P_{41} ; l_{1 A 41}=7,4$ & $8,5 \div 8,7$ & $6,10 \div 6,9$ & 4,2 & 1,1 \\
\hline$P_{21} ; I_{\text {IA21 }}=7,6$ & 9,1 & $6,9 \div 7,9$ & 3,0 & - & $P_{42} ; l_{\mid A 42}=7,7$ & $9,7 \div 9,9$ & $6,9 \div 7,2$ & $3,20 \div 4,2$ & - \\
\hline
\end{tabular}


Note: $1 . l_{I A i}-$ an integral indicator of the attractiveness of the innovative project of the i-th enterprise.

2. Designation of enterprises: $P_{1}$ - LLC "EMF", $P_{2}$ - PJSC "Experimental Electrical Plant", $P_{3}-$ PJSC

"Donbasenergo" (Kyiv), $P_{4}$ - LLC "Equives", $P_{5}$ - LLC "Ekra Caucasus Ukraine", $P_{6}-$ LLC

"Elektropivdenmontazh", $P_{7}$ - LLC "Enpaselectro", $P_{8}$ - LLC "Eurotechenergo", $P_{9}$ - SE "Zorya

Mashproekt", $P_{10}$ - LLC "Leader Electric", $P_{11}$ - PJSC "Nasosenergomash", $P_{12}$ - LLC "Cherkasy", $P_{13}$ - LLC

"MHM Ukraine", $P_{14}$ - SE "Naukanaftogaz", $P_{15}$ - SPE "Energosystem", $P_{16}$ - LLC "Consulting Engineering

Center", $P_{17}$ - LLC "SIKAM Ukraine", $P_{18}$ - SPE PJSC "Radium", $P_{19}$ - LLC SENSE, $P_{20}$ - SE "National Atomic

Energy Generating Company" Energoatom ", $P_{21}$ - LLC" Kotloturboprom ", $P_{22}$ - PJSC" Sumygaz ", $P_{23}$ -

LLC" Gazmashservice ", $P_{24}$ - Kremenchug branch of LLC" NVF "Alcon", $P_{25}$ - PE "Poltava-Teploprilad", $P_{26}$ - SPE "Naftogaztechnologiya", $P_{27}$ - LLC SPE "UEK", $P_{28}$ - CJSC "INTEC", $P_{29}$ - LLC VP "Kharkivenergoremont $K^{\prime}, P_{30}$ - PJSC "NTT" Ukrpromenergo ", $P_{3}$ - SE "Eastern Mining and Processing Plant", $P_{32}$ - SE "Resins", $P_{33}$ - SE "Ukrainian Research and Design and Exploration Institute of Industrial Technology ", $P_{34}-\mathrm{SE}$ " Energoproekt ", $P_{35}$ - SE" Atomenergobudproekt ", $P_{36}$ - JSC" Ecosystem ", $P_{37}$ - SE" Engineering and Technical Training Center for Atomic Energy " , $P_{38}$ - State Enterprise "Central Enterprise for Radioactive Waste Processing", $P_{39}$ - State Enterprise "Barrier", $P_{40}$ - OJSC "Kharkiv Research and Design Institute Energoproekt", $P_{41}$ - State Enterprise "Chornobylpromenergobud", $P_{42}$ - State Enterprise Engineering and Technical Training Center for Atomic Energy ".

Figure 2. Integral indicator of investment attractiveness of an innovative project

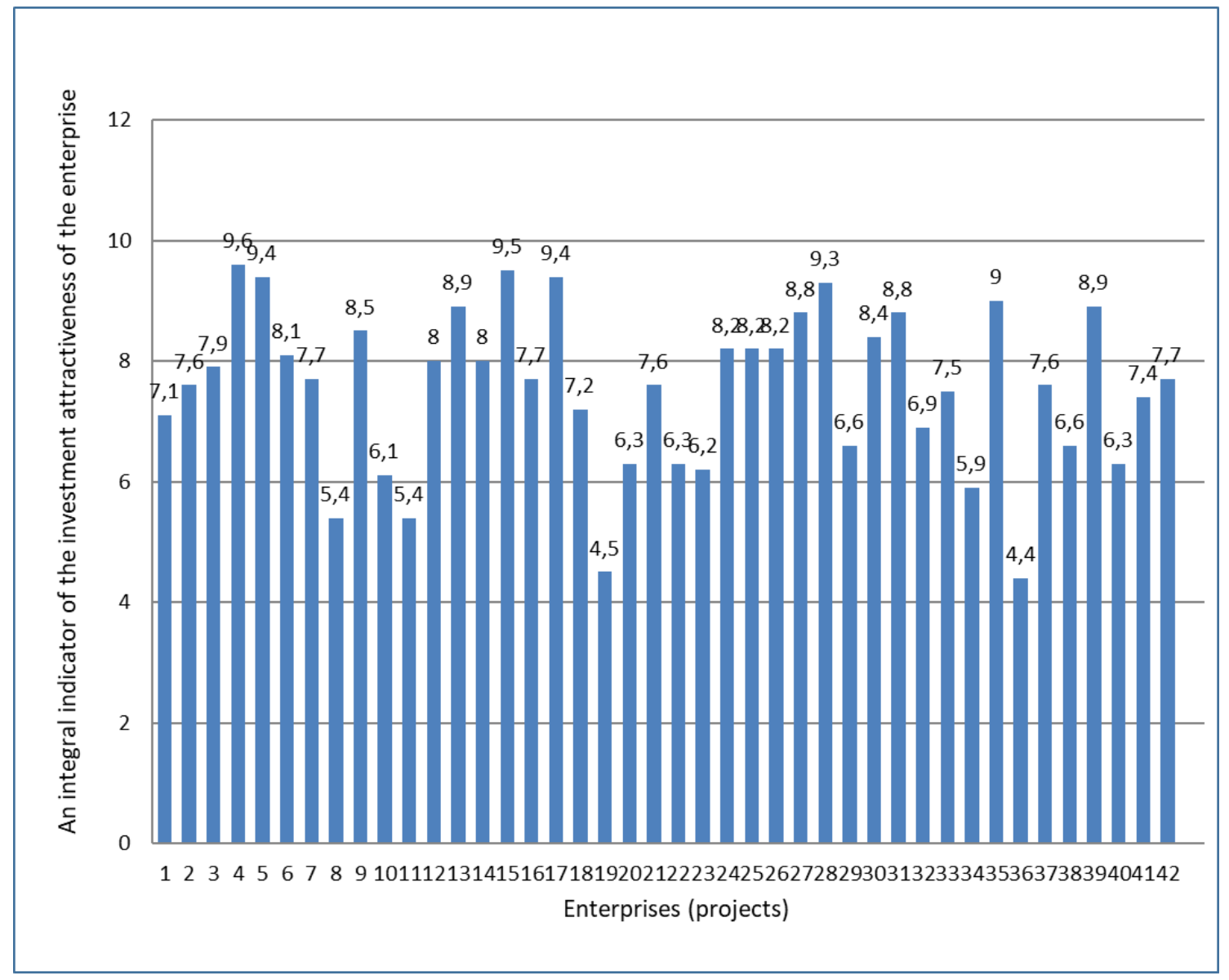


According to the results of the study, it was concluded that the innovative projects of the following enterprises have a high level of investment attractiveness: Equives LLC (P4), Ekra Caucasus Ukraine LLC (P5), Electropivdenmontazh LLC (P6), Zorya Mashproekt State Enterprise (P9), LLC "MGK Cherkasy" (P12), LLC "MHM Ukraine" (P13), SE "Naukanaftogaz" (P14), SPE "Electronasos-Service" (P15), LLC "SIKAM Ukraine" (P17), Kremenchug branch LLC Alkon (P24), PE Poltava-Teploprilad (P25), SPE Naftogaztekhnologiya (P26), LLC SPE UEK (P27), CJSC Enrichment Plant (P31), SE Ukrainian Design and Design -technological institute "Atomenergobudproekt" (P35), SE "Barrier" (P39).

In addition to economic, social and environmental effects can be obtained from the implementation of the investment project. Therefore, when developing a project, an assessment should be made of its social and environmental results, as well as the costs associated with them.

In addition to assessing the financial attractiveness of an innovative project, it is necessary to determine the level of its risk. In the world practice of investment management, various methods are used to assess the effectiveness of investment projects in terms of risk and uncertainty, the most common of which are the following methods: the method of discounting (risk premium); reliability coefficient method; sensitivity analysis of performance indicators (NPV, IRR, etc.); scripting method; methods of game theory (maximin criterion, maximax criterion, etc.); building a "decision tree"; simulation modeling by the Monte Carlo method.

The description of these methods is presented in detail in many literature sources $[2,6,9$, 11], highlights the advantages and disadvantages of each of them in the case of their application in practice.

\section{Conclusions.}

The study of the state of innovative projects of industrial enterprises allows us to conclude that the prospects for increasing the level of their investment attractiveness should be based on the tools of their integrated evaluation for the development and adoption of effective investment decisions.

Based on the generalized factors of investment attractiveness of innovative projects of industrial enterprises, the authors highlight the problem of comparing alternative investment options in terms of multi-criteria evaluation of options. Based on the use of the integrated criterion of efficiency, the best investment options are selected. Taking into account the other efficiency criteria is carried out at the final stage of selection and final decision-making on the implementation of innovative projects in the investment process.

To solve this problem, the authors identified in the technical and economic characteristics of innovative projects a number of unambiguously interpreted components that form the level of investment attractiveness of innovative projects and allow to systematize methodological tools for assessing the level of investment attractiveness and justify decisions on their implementation in industrial and commercial activities.

The study showed that a qualitative assessment of the investment attractiveness of enterprises as an element of ensuring the competitiveness of innovative projects requires the study of:

- statistical indicators of market movements;

- indicators of market structure;

- price competition;

- political situation. 
The authors have developed a methodological approach to the formation of a system for assessing the innovation and investment attractiveness of industrial enterprises as an element of ensuring the competitiveness of innovative projects.

\section{References}

1. Plaskova, N., Prodanova, N., Akhmetshin, E., Chaya, V. (2019). Assessment of the investment attractiveness of innovative companies using the scenario method. Education Excellence and Innovation Management through Vision 2020. pp. 7766-7773. URL: https://www.researchgate.net/publication/335082903

2. Rzayeva, T.G., Gritsyuk, M.V. (2016). Indicators of estimation and analysis of investment attractiveness of the enterprise in the context of existing methods. Economic sciences. Bulletin of the Khmelnytsky National University, 3(1), 94-102.

3. Safiullin, A.R., Shakirzyanov, N.R., Ravzieva, D. I. (2018). Infrastructure for regional development investment projects. Journal of Social Sciences Research. Special Issue 1. pp.1284. URL: doi: $10.32861 /$ jssr.spil.

4. Nikonova, T.V., Yusupova, L.M., Kodolova, I.A., Kalimullina, R. R. (2018). Cluster approach as a factor of increasing the investment attractiveness of the region. Journal of Social Sciences Research. Special Issue 5. pp.70-74. URL: doi:10.32861/jssr.spi5.70.74

5. Naumov, A.A., Kryukov, S. V. (2012). Application of scenario approach to the assessment of efficiency of investment projects. Innovation. 20. pp. 40-45.

6. Kolmykova, T.S. (2015). Investment analysis: studies. Allowance. Moscow: INFRA-M. 208 p.

7. Kolesnichenko E.A. (2015). Methodological tools for assessing the level of investment attractiveness of startups. Investment analysis, 12 (411), pp. 2-11.

8. Pererva, P., Besprozvannykh, O., Tiutlikova, V., Kovalova, V., Kudina, O., Dorokhov, O. (2019). Improvement of the Method for Selecting Innovation Projects on the Platform of Innovative Supermarket. TEM Journal, 8(2), pp. 454-461. URL: DOI: 10.18421/TEM82-19

9. Prokopyeva, M.V. (2009). Assessment of the investment attractiveness of innovative projects. Young scientist, 2 (2), pp. 81-84. URL: https://moluch.ru/archive/2/137/

10.Perereva, P., Kobielieva, T., Tkachova, N., Tkachov, M., Diachenko, T. (2021) Management of relations with enterprise stakeholders on the basis of value approach. Problems and Perspectives in Management, 19(1), pp. 24-38. URL: http://dx.doi.org/10.21511/ppm.19(1).2021.03

11.Kosenko, O., Cherepanova, V., Dolyna, I., Matrosova, V., Kolotiuk, O. (2019). Evaluation of innovative technology market potential on the basis of technology audit. Innovative Marketing, 15(2), pp. 30-41. URL: DOI: 10.21511/im.15(2).2019.03

12.Hutsan, O., Kobieliev, V., Kosenko, A., Kuchynskyi, V. (2018). Evaluating elasticity of costs for employee motivation at the industrial enterprises. Problems and Perspectives in Management, 16(1), pp. 124-132. URL: http://dx.doi.org/10.21511/ppm.16(1).2018.12 
